\title{
Regulating Australia's participation in the Orphanage Industry
}

\begin{abstract}
Orphanages harness the goodwill of volunteers, visitors and donors to generate funding. However, in recent years, evidence has emerged that in some cases children are being recruited or trafficked into orphanages in order to generate profit from this goodwill. This has become known as the 'orphanage industry' and the recruitment of children into orphanages for the purpose of profit and exploitation is 'orphanage trafficking'.

Australia is reported to be the largest funder of residential care for children in South East Asia. In 2017, Australia became the first government in the world to consider orphanage trafficking as a form of modern slavery. This article traces the evolution of the recognition of orphanage trafficking broadly, and then focuses on recommendations made by the Australian government following the release of its 2017 Hidden in Plain Sight Report. This article analyses the emerging policy and legislative reforms that are being undertaken by the Australian government and recommends further development to ensure that funding and finances are appropriately directed to divest from orphanages and instead support burgeoning care reform in the South Asian region. Finally, the article responds to critiques of the Australian government's standpoint on orphanage trafficking as it relates to the over-reliance on institutional care, and provides clarification on why a criminal justice response to orphanage trafficking is appropriate.
\end{abstract}

Keywords: Alternative care, Orphanage trafficking, Modern slavery, Orphanage tourism, Voluntourism, Residential care 


\section{Introduction}

Orphanage trafficking, where children are recruited or transferred into residential care institutions for the purpose of exploitation and profit, is regarded as an emerging form of child exploitation internationally (Bales, Hedwards, \& Silverman, 2018). In 2017, the Australian government considered how Australians might be participating in the orphanage industry through funding, visiting and volunteering in orphanages as part of its Inquiry into whether Australia should have a Modern Slavery Act. The Inquiry considered extensive evidence submitted by Australian and international non-government organisations and experts on the over-reliance on institutionalisation of children globally and Australia's potential contribution to the issue via funding and voluntourism. A particular focus of the Inquiry related to the recruitment of children into residential care facilities for the purpose of exploitation and profit, a process known as orphanage trafficking (van Doore, 2016). The Hidden in Plain Sight Report released in late 2017 included the world-first recommendation that Australia should regard orphanage trafficking as a form of modern slavery (Australian Government, 2017).

This paper outlines the steps that Australia has taken since the release of the Hidden in Plain Sight Report to stem the flow of funding and volunteers to orphanages overseas. It outlines how policy and legislative reform have taken place in the regulation of charities, voluntourism and modern slavery to attempt to impact Australia's unwitting participation in the 'orphanage industry' (Cheney \& Rotabi, 2015). The paper details government action from advertising and awareness campaigns to the requirement to report on the mitigation of the potential of orphanage trafficking in corporate supply chains.

More broadly, while it argues that a spotlight on orphanage trafficking has enabled child protection advocates to re-enliven and re-educate policy makers and legislators on the harms of institutionalisation, it also highlights that this approach has not been without critics. In particular, child protection experts warn that a concentration on addressing orphanage trafficking and 'scam orphanages' can obfuscate awareness of the nuances of alternative care (Nhep \& van Doore, 2018), and also that employing trafficking discourse to address the social issue of the over-use of institutional care of children may not be beneficial (Bearup, 2019).

\section{Recognising Orphanage Trafficking}

The phenomenon that has come to be known as 'orphanage trafficking' was first identified by non-government organisations working in child protection in low- and middle-income nations in the 2000's, where links between child exploitation, institutionalisation and profit were detailed in fieldwork and research in Nepal (Dhungana, Basnet, Rai, \& Pradhan, 2005; Punaks \& Feit, 2014a), Indonesia (Martin \& Sudraja, 2006) and Cambodia (UNICEF, 2011). Some of this research suggested that the displacement of children from their biological families into residential care could be a form of trafficking but did not provide a legal basis for the assertion. For example, a report by Next Generation Nepal (NGN) on the paradox of orphanage volunteering noted:

NGN uses the terms 'trafficked' and 'trafficking' throughout this report to refer to situations where children have been fraudulently displaced from their 
families by brokers and harbored in orphanages to be used for commercial purposes...We recognize that whether or not such cases are legally considered to be 'trafficking' is contested (Punaks and Feit, 2014b, p.1).

In 2016, the Global Slavery Index listed orphanage tourism as a practice of exploitation in its Cambodia narrative, outlining how some residential care institutions were forcing children to perform dances for tourists, or to perform farm work or distribute flyers to fundraise (Walkfree Foundation, 2016). The Government of Sweden also outlined the links between orphanage tourism and exploitation in its 2016-2018 Action Plan to protect children from human trafficking, exploitation and sexual abuse stating that:

the general public must also be informed of the existence of exploitation and human trafficking in children in connection with orphanage tourism and voluntary work in other countries, and how this can contribute to the increasing vulnerability of children" (Swedish Ministry of Health and Social Affairs, 2016, p.12).

Throughout the 2000's, there was extensive media coverage on children being recruited into orphanages to ensure a sufficient supply of 'orphans' to meet the demand of orphanage tourism, where tourists from high-income nations pay to volunteer with orphans (see for eg. Pattisson, 2014; Sigdel, 2014). In these media reports, a link between the displacement of children into orphanages and child trafficking was often made anecdotally, but again without legal basis.

In 2016, the first legal argument that paper orphaning, where children are recruited into orphanages and forced to pose as orphans for the purpose of exploitation and profit, should be considered as child trafficking under international law was published (van Doore, 2016). In 2017, following extensive advocacy by many parties (Punaks, 2017), the United States Trafficking in Persons Report recognised the link between tourists' desire to visit and volunteer with orphans, and the recruitment of children into orphanages to pose as orphans to meet this demand. The 2017 Nepal narrative stated:

Under false promises of education and work opportunities, Nepali parents give their children to brokers who instead take them to frequently unregistered children's homes in urban locations, where they are forced to pretend to be orphans to garner donations from tourists and volunteers; some of the children are also forced to beg on the street (United States Department of State, 2017, p.296). 
The Trafficking in Persons Report is regarded as a comprehensive resource for anti-human trafficking efforts internationally and has been touted as the most successful "single initiative in exposing the breadth and extent of contemporary exploitation of individuals for private profit" (Gallagher, 2012, p.174-175), compelling governments to take action where otherwise they would not have done so. The Trafficking in Persons Report 2018 included a special interest topic of 'Child Institutionalization and Human Trafficking', specifically highlighting that children were being trafficked into orphanages for the purpose of exploitation and profit through voluntourism (United States Department of State, 2018, p.22).

The inclusion in the Trafficking in Persons Reports 2017 and 2018 of the links between tourism and recruitment into orphanages represented a watershed moment for child protection advocates and non-governmental organisations that had been working in the area for many years. It was an official recognition that the practice of recruiting and transferring children into orphanages to meet the demand of orphanage tourism and funding could be considered a form of child trafficking.

\section{The Australian Modern Slavery Inquiry}

In addition to the Trafficking in Persons Report, there have been other major breakthroughs in the recognition of paper orphaning and orphanage trafficking. In particular, the Australian Parliament became the first government to formally consider paper orphaning and orphanage trafficking as part of its Inquiry into whether Australia should have a Modern Slavery Act in 2017. The Inquiry received many submissions from child protection organisations on the issues of child exploitation, voluntourism and orphanage trafficking, arguing that Australia should recognise orphanage trafficking as a form of modern slavery. At the request of the Inquiry Committee, a survivor of child exploitation in residential care from Cambodia gave testimony regarding her experiences of living in an orphanage. The moving testimony remains available on the Inquiry's webpage and was detailed in the Hidden in Plain Sight Report (Australian Government, 2017, p.227-228). The report outlined paper orphaning and orphanage trafficking as "the active recruitment of children into orphanages or residential care institutions in developing States for the purpose of ongoing exploitation, particularly through orphanage tourism" (Australian Government, 2017, p.225) and recommended that orphanage trafficking should be recognised as a form of modern slavery.

The Modern Slavery Act 2018 (Cth) was passed by parliament on the 29th of November 2018 and came into effect on the 1st of January 2019. In a press release regarding the Bill passing the House of Representatives in September 2018, Assistant Minister Senator the Honourable Linda Reynolds stated:

As a result of this legislation, Australia will also be the first nation in the world to recognise orphanage trafficking as a form of modern slavery. This means that a reporting entity with activities or supply chains which involve orphanages will need to assess and report on any risks relating to modern slavery in these operations (Reynolds, 2018). 
The Act provided a definition of modern slavery that is considered broad enough to encapsulate orphanage trafficking. This was reinforced by an explicit reference to orphanage trafficking and child exploitation in institutions found in Item 50 of the Explanatory Memorandum to the Modern Slavery Bill 2018 (Australian Government, 2018).

However, contrary to the recommendations of the Inquiry, the Act did not create any modern slavery offences for orphanage trafficking. Instead, the Act exists as a supply chain reporting mechanism for entities that meet a test of over AUD $\$ 100$ million revenue per annum. This means that according to the Act, entities that fund or send volunteers to residential care institutions, and which meet the reporting threshold, are required to report on how they have assessed and mitigated the risk of orphanage trafficking and child exploitation in orphanages in their supply chains in their annual Modern Slavery Statements.

\section{Enacting Reform}

Apart from introducing the Modern Slavery Act 2018 (Cth), the Australian Government has enacted a number of other reforms regarding orphanage tourism and funding, stemming from the recommendations made in the Hidden in Plain Sight Report and representing a holistic response to the over-reliance on institutional care for vulnerable children in low- and middleincome countries. For example, in accordance with recommendation 34 stating that the Australian government should fund research into institutional care, the Australian Institute of Criminology published a research paper on orphanage voluntourism and child exploitation (Lyneham \& Faccini, 2019). Recommendations 34 and 37 have also been enacted via the Australian Government actively bringing the issue to the fore at the 2018 Commonwealth Heads of Government Meeting (CHOGM) by hosting a side-event on orphanage trafficking, and to other international settings such as the Alliance 8.7 and Asia Pacific Economic Corporation (APEC) meetings. These meetings have led to growing international awareness of the issues of orphanage trafficking, and other countries are now following Australia's lead. For example, the Dutch Government held a Parliamentary Roundtable on orphanage tourism in March 2019 (Kingdom of the Netherlands, 2019) and the United Kingdom government who recently considered orphanage trafficking as part of the United Kingdom Independent Expert Review of the Modern Slavery Act 2015 (United Kingdom, 2019).

In line with recommendations 35 and 36, an awareness campaign highlighting the dangers of orphanage tourism was launched through the Department of Foreign Affairs and Trade (DFAT) website in early 2018, explicitly discouraging tourists and volunteers from visiting or volunteering in orphanages when travelling overseas. In addition, the Minister for Education at the time committed to engaging with the departments of Education across Government to ensure schools and universities were aware of the potential harm of orphanage volunteering and to discourage schools and universities to vet their volunteering programs.

Recommendation 38 suggested that Australia should ensure that government funding does not support residential care institutions that do not meet the requirements of the Convention on the Rights of the Child and United Nations Guidelines for the Alternative Care of Children. In response, the Department of Foreign Affairs and Trade introduced explicit funding guidelines for the new Friendship Grant program, outlining that activities that involve unskilled volunteers supporting orphanages or residential care institutions would be ineligible for funding under the program. 
Recommendation 39 provided that the Australian Charities and Not for Profit Commissions should introduce External Conduct Standards to regulate how charities interacted with the provision of residential care and vulnerable children overseas. Introduced in 2019, the External Conduct Standards include how charities should mitigate their risks with regard to orphanage trafficking and child exploitation in residential care institutions.

The remaining recommendations pertained to establishing a register of organisations supporting residential care institutions that uphold the Convention on the Rights of the Child and United Nations Guidelines for the Alternative Care of Children, and helping organisations who do not meet this criteria to either seek to meet it, or to divest from supporting residential care in a responsible manner, and creating an offence and penalties for individuals or entities facilitating, enabling, organising, benefitting or profiting from tourist visits to, or funding of, orphanages, that do not comply with the criteria. The Australian Government has not formally responded to these recommendations as yet.

\section{Critiquing the trafficking lens}

It should be noted that the spotlight on the links between the over-reliance on institutional care in low- and middle-income countries and child trafficking has not been without critique. For example, much media attention has focused on the notion of 'scam orphanages' that are set up as for-profit enterprises, which can be argued might obfuscate the ability to address the over-reliance on institutional care as a nuanced issue of how countries enact alternative care reform (Nhep \& van Doore, 2018).

Another critic stated that child protection organisations utilising a trafficking framework to address the over-use of institutional care in the Modern Slavery Inquiry displaced "more balanced critiques of institutional care" related to the limited investments of governments in social welfare (Bearup, 2019). However, this critique fails to acknowledge or provide a solution for where orphanage trafficking does occur, instead seeming to regard it as part of a social welfare issue rather than a criminal offence. Where children are recruited into orphanages for the purpose of exploitation and profit, it is imperative that it is regarded as a criminal offence to enable prosecution of those who participate in this process knowingly. Whether Australia will proceed to create such an offence is yet to be seen, but is strongly recommended.

Whilst orphanage trafficking was certainly highlighted throughout the course of the Modern Slavery Inquiry, perhaps disproportionately so at times in the media, child protection organisations and experts, including the author, have consistently explained that recognising orphanage trafficking as a form of modern slavery is not intended to address the entirety of the issue of over-reliance on institutional care as a first port of call for child vulnerability. In order to address this, a range of divestment strategies coupled with government reform for funding are necessary (Nhep \& van Doore, 2018). The Hidden in Plain Sight Report agrees that a holistic response is a proportionate way forward.

\section{Conclusion}

The action of the Australian Government in both holistically regulating and educating on the issues of orphanage tourism and trafficking is setting a standard for other countries to follow suit, ensuring that vulnerable children overseas are not institutionalised inappropriately due to 
funding streams and demand for orphanage voluntourism experiences. Australia is setting the pace in providing a whole of government response to the issue rather than merely focusing on a criminal justice response. The Australian government has enacted policy and legislative reform including the regulation of funding rules for Australian Friendship grants, the Smart Volunteer campaign advising volunteers of the potential harms of orphanage voluntourism, and the inclusion of how entities are mitigating the risk of orphanage trafficking in their supply chains in reporting requirements of the Modern Slavery Act 2018 (Cth).

The growing recognition of orphanage trafficking internationally has led to other countries such as the Netherlands and United Kingdom now taking action on orphanage tourism and orphanage trafficking. As the world leader in recognising orphanage trafficking, Australia has set an example for other countries to follow in taking action on orphanage trafficking and the issue of their contribution to the inappropriate over-reliance on residential care for children throughout the South-East Asian region, as well as globally. It is essential that the Australian government continues to build on the momentum that has been established by continuing to enact the reforms recommended in the Hidden in Plain Sight Report. 


\section{References}

Australian Government. (2018). Explanatory Memorandum to the Modern Slavery Bill 2018 (Cth). Canberra, Australia: Australian Government.

Australian Government, Joint Standing Committee on Foreign Affairs Defence and Trade, Commonwealth of Australia. (2017). Hidden in Plain Sight: An inquiry into establishing a Modern Slavery Act in Australia. Canberra. Australia: Australian Government.

Dhungana, M, Basnet, B, Rai, U and Pradhan, R. (2005). Fact-finding Mission on Displacement of Children from Humla 29 December 2004 - 1 January 2005. Kathmandu, Nepal: UNICEF and Forum for Women, Law and Development, Nepal.

Bales, K, Hedwards, B and Silverman, B. (2018). Modern Slavery Research: the UK Picture. A research report from the Office of the Independent Anti-Slavery Commissioner and the University of Nottingham's Rights Lab, London, United Kingdom: Office of the Independent Anti-Slavery Commissioner and the Rights Lab, University of Nottingham.

Bearup, L.S. (2019). 'The Praxis of Protection: Working with - and Against - Human Trafficking Discourse' in Winterdyk, J.A. and Jones, J. (Eds.). The Palgrave International Handbook of Human Trafficking. London, United Kingdom: Palgrave Macmillan.

Cheney, K. E., \& Rotabi, K.S. (2015). Addicted to orphans: How the global orphan industrial complex jeopardizes local child protection systems. Conflict, Violence and Peace, 1-19.

Gallagher, AT. (2012). Human Rights and Human Trafficking: A Reflection on the Influence and Evolution of the U.S Trafficking in Persons Reports in Brysk, A and Choi-Fitzpatrick, A. (eds). From human trafficking to human rights: Reframing contemporary slavery. Philadelphia, United States of America: University of Pennsylvania Press.

Kingdom of the Netherlands. (2019). Volunteer and Orphanage Tourism Abroad. Retrieved from $<$ https://www.nederlandwereldwijd.nl/reizen/vrijwilligerswerkweeshuistoerisme-buitenland $>$.

Lyneham, S., \& Facchini, L. (2019). Benevolent harm: Orphanages, voluntourism and child sexual exploitation in South-East Asia. Trends and Issues in Crime and Criminal Justice, (574), 1.

Nhep, R. and van Doore, K.E. (2018). Divesting the Orphanage Industry: Ending Australia's participation in the business model of orphanage trafficking. Melbourne, Australia: ReThink Orphanages Australia.

Martin, F and Sudraja, T. (2006). A Rapid Assessment of Children's Home in Post-Tsunami 
Aceh. Jakarta, Indonesia: Save the Children UK and Ministry of Social Affairs.

Pattisson, P. (2014). Nepal's bogus orphan trade fuelled by rise in voluntourism. The Guardian. London: United Kingdom. Retrieved from $<$ http://www.theguardian.com/globaldevelopment/2014/may/27/nepal-bogus-orphan-trade-voluntourism>.

Ptwaks, M and Feit, K. (2014a). Orphanage voluntourism in Nepal and its links to the displacement and unnecessary institutionalisation of children. Institutionalised Children Explorations and Beyond, 1(2), 179.

Punaks, M and Feit, K. (2014b). The Paradox of Orphanage Volunteering: Combating child trafficking through ethical voluntourism. Kathmandu, Nepal: Next Generation Nepal,

Punaks, M. (2017). Exploiting children in orphanages recognised as trafficking. London, United Kingdom; Anti-Slavery International. Retrieved from $<$ https://www.antislavery.org/orphanage-trafficking/>.

Reynolds, L. Assistant Minister for Home Affairs. (2018). Modern Slavery Bill passes House of Representative. Canberra, Australia: Department of Home Affairs. Retrieved from $<$ https://minister.homeaffairs.gov.au/lindareynolds/Pages/modern-slavery-bill-passeshouse-of-representatives.aspx $>$.

Sigdel, C. (2014). Not all is well with "orphanages": Children's homes come into limelight with a number of cases of abuse and trafficking. Kathmandu Post. Kathmandu: Nepal. Retrieved from $<$ http://kathmandupost.ekantipur.com/news/2014-09-16/not-all-iswell-with-orphanages.html>.

Government of Sweden, Ministry of Health and Social Affairs. (2016). About what must not happen - a road map: The Swedish Government's action plan to protect children from human trafficking, exploitation and sexual abuse 2016-2018 - English summary. Stockholm, Sweden: Government of Sweden.

UNICEF. (2011). With the best intentions: A study of attitudes towards residential care in Cambodia. Phnom Penh, Cambodia: UNICEF \& Ministry of Social Affairs, Veterans and Youth Rehabilitation.

United Kingdom (2019). UK Government Response to the Independent Review of the Modern Slavery Act 2015. London, United Kingdom: Crown Publications.

United States Department of State. (2017). Trafficking in Persons Report 2017. Washington, United States of America: United States of America Department of State.

United States Department of State. (2018). Trafficking in Persons Report 2018. Washington, United States of America: United States of America Department of State.

van Doore, K. E. (2016). Paper orphans: Exploring child trafficking for the purpose of 
orphanages. The International Journal of Children's Rights, 24(2), 378-407.

Walkfree Foundation. (2016). Global Slavery Index 2016. Perth, Australia: The Minderoo Foundation Pty Ltd. 